\title{
Structural pattern of the Todos Santos Coastal Plain, based on geophysical data
}

\section{Patrón estructural de la Planicie Costera de Todos Santos, con base en datos geofísicos}

\author{
Marco A. Pérez-Flores \\ Francisco Suárez-Vidal* \\ Luis A. Gallardo-Delgado \\ Antonio González-Fernández \\ Rogelio Vázquez \\ División de Ciencias de la Tierra, CICESE \\ Km 107 Carretera Tijuana-Ensenada \\ Ensenada, Baja California, México \\ *E-mail: fsuarez@cicese.mx
}

Recibido en marzo de 2003; aceptado en marzo de 2004

\begin{abstract}
A set of gravity and magnetic data taken within the Todos Santos Coastal Plain between 1962 and 2000 from land, sea and air is used to integrate the structural framework and tectonic model of this area. The present work collected all the available data, homogenized them, and maintained them at their original altitude. A new technique of joint inversion for gravity and magnetic data from three-dimensional structures was applied. As a result, a well-defined topographic map of the granitic-andesitic basement was obtained and previously unknown geological structures were depicted. Several cross-sections were made from the three-dimensional model obtained, establishing the Todos Santos Coastal Plain structural pattern as a typical pull-apart basin associated with a tectonic fore-arc during the subduction of the Farallón Plate in Late Mesozoic and Early Cenozoic time.
\end{abstract}

Key words: structure, coastal plain, geophysical data, gravity, magnetics.

\section{Resumen}

Se integró el marco estructural y el modelo tectónico de la Planicie Costera de Todos Santos, utilizando un conjunto de datos gravimétricos y magnéticos tomados entre 1962 y 2000 en tierra, aire y mar. En el presente trabajo se integró toda la información disponible, se homogeneizó y se mantuvo a su altitud original. Se empleó una nueva técnica de inversión conjunta de datos gravimétricos y magnéticos para estructuras tridimensionales. Como resultado se obtuvo un mapa topográfico del basamento granítico-andesítico, donde se visualizan rasgos geológicos desconocidos hasta este trabajo. Se hicieron algunas secciones a partir del modelo tridimensional, en los que se establece el patrón estructural de la Planicie Costera de Todos Santos, el cual es típico de una cuenca extensional (pull-apart basin) asociada con un frente de arco en un ambiente tectónico durante la subducción de la placa Farallón a final del Mesozoico y principios del Cenozoico.

Palabras clave: estructura, planicie costera, datos geofísicos, gravimetría, magnetometría.

\section{Introduction}

The Todos Santos Coastal Plain was defined by Gastil et al. (1975) and includes the city and bay of Ensenada de Todos los Santos and the Ejido Sánchez Taboada (Maneadero) basin, being different from the Ensenada Block defined by Gastil et al. (1975) (fig. 1). The Todos Santos Coastal Plain is an area of about 34,000 ha (Aranda, 1983), forming a half-graben bound by several active faults that generate a high seismic risk and create a geologic hazard to the region (Wong, 1980; González and Suárez, 1984; Rockwell et al., 1987; Ortega, 1988; Suárez et al., 1991). This geomorphic province is a half-graben filled with $2000 \mathrm{~m}$ of sediments of unknown age. There are few geological studies and some geophysical surveys on the Todos

\section{Introducción}

La Planicie Costera de Todos Santos fue definida por Gastil et al. (1975) e incluye la ciudad y bahía de Ensenada de Todos los Santos y la cuenca del Ejido Sánchez Taboada (Maneadero), siendo diferente del Bloque de Ensenada definido por Gastil et al. (1975) (fig. 1). La Planicie Costera de Todos Santos cubre un área de 34,000 ha (Aranda, 1983) y forma un semigraben rodeado por varias fallas activas que generan un alto riesgo sísmico y representan un peligro geológico para la región (Wong, 1980; González y Suárez, 1984; Rockwell et al., 1987; Ortega, 1988; Suárez et al., 1991). La provincia geomórfica es un semigraben relleno de $2000 \mathrm{~m}$ de sedimentos de edad desconocida. Existen pocos estudios 


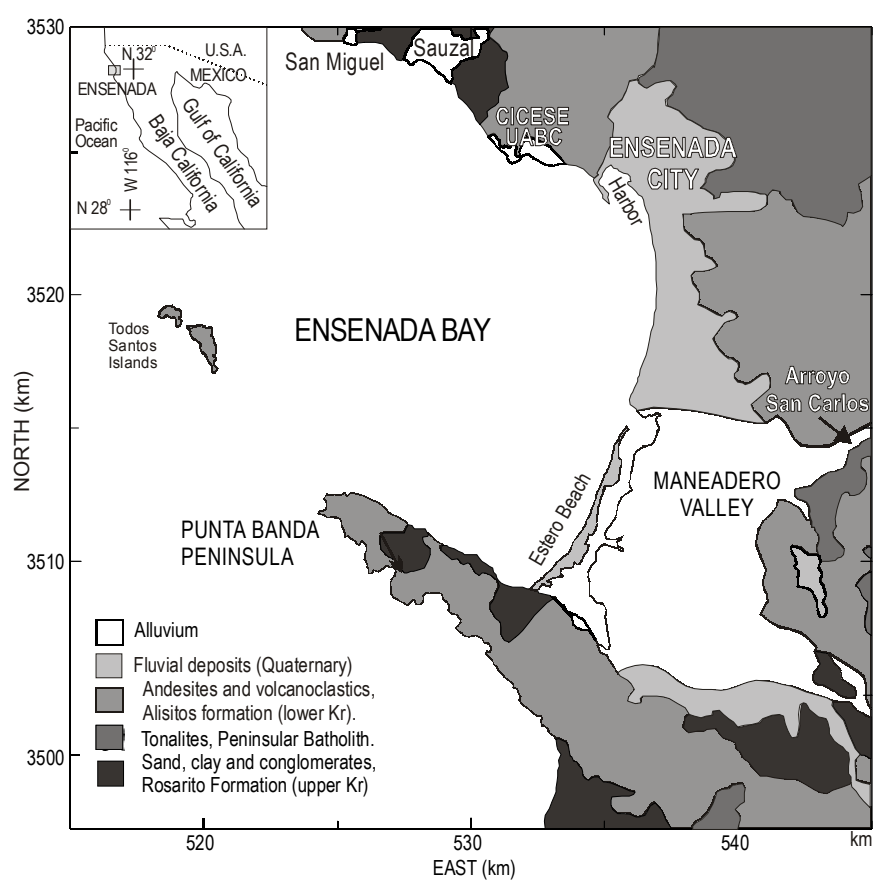

Figure 1. Location of Todos Santos Bay (Mexico) and its surface geology. Figura 1. Localización de la Bahía de Todos Santos (México) y su geología superficial.

Santos Coastal Plain that describe the general geology, structural geology and related tectonic process which acted in this region through geological time, among them the aeromagnetic study made by Consejo de Recursos Naturales No Renovables (1962), the geological reconnaissance in Valle Dorado by Schroeder (1967), and the gravity survey made in Maneadero Valley by Dowdy (1977). Vázquez (1980) carried out a geophysical survey, applying electrical resistivity, selfpotential, tellurics and potential field. Based on the gravity data, maximum depth of the basement was estimated along two profiles oriented perpendicular to the Agua Blanca fault (fig. 2). One was located along the Estero Beach sand bar that separates the Punta Banda coastal lagoon from the open ocean and in this profile the basement depth was estimated to be $1700 \mathrm{~m}$, while in the second profile, located $5 \mathrm{~km}$ to the SE from the previous, the basement was estimated to be $900 \mathrm{~m}$ deep. These calculations were made with a density contrast of $0.35 \mathrm{~g} \mathrm{~cm}^{-3}$. Fabriol et al. (1982) worked with telluric and gravity measurements from Vázquez (1980) in Maneadero, and reported a density contrast between sediments and andesites of $0.7 \mathrm{~g} \mathrm{~cm}^{-3}$ and a fault in Maneadero Valley parallel to Agua Blanca (fig. 2). They interpreted two bidimensional profiles and determined the depth of the Maneadero basin in several places. Cruz (1986) interpreted data from a gravity survey along Arroyo San Carlos and Maneadero and determined the depth to the basement at $650 \mathrm{~m}$, being shallower to the north. Aguero (1986) integrated most of the available potential field data from the Maneadero area. Recently, González-Fernández et al. (2000) conducted a bathymetric, magnetic and gravity survey along the Punta Banda peninsula, and found a set of geológicos y algunas investigaciones geofísicas de la Planicie Costera de Todos Santos que describen la geología general, la geología estructural y los procesos tectónicos que operaron en esta región en tiempo geológico, entre ellos el estudio aeromagnético del Consejo de Recursos Naturales No Renovables (1962), la exploración geológica en Valle Dorado de Schroeder (1967) y el estudio gravimétrico en el Valle de Maneadero de Dowdy (1977). Vázquez (1980) realizó un estudio de métodos potenciales con aplicaciones a la geohidrología del Valle de Maneadero. Con base en los datos gravimétricos, se estimó la profundidad máxima del basamento a lo largo de dos perfiles orientados de manera perpendicular a la falla de Agua Blanca (fig. 2), uno localizado a lo largo de la barra de arena de Estero Beach que separa la laguna costera de Punta Banda del mar abierto y el otro a $5 \mathrm{~km}$ al SE del anterior. La profundidad del basamento se estimó a $1700 \mathrm{~m}$ en el primer perfil y a $900 \mathrm{~m}$ en el segundo. Estos cálculos se hicieron con un contraste de densidad de $0.35 \mathrm{~g} \mathrm{~cm}^{-3}$. Fabriol et al. (1982) trabajaron con mediciones telúricas y gravimétricas de Vázquez (1980) en Maneadero y reportaron un contraste de densidad entre sedimentos y andesitas de $0.7 \mathrm{~g} \mathrm{~cm}^{-3}$, así como una falla en el Valle de Maneadero paralela a Agua Blanca (fig. 2); interpretaron dos perfiles bidimensionales y determinaron la profundidad de la cuenca de Maneadero en varios lugares. Cruz (1986) interpretó los datos de un estudio gravimétrico a lo largo del Arroyo San Carlos y Maneadero, y determinó la profundidad del basamento a $650 \mathrm{~m}$, resultando más somero hacia el norte. Aguero (1986) integró la mayoría de los datos de campo potenciales disponibles para el área de Maneadero. Recientemente, González-Fernández et al. (2000) llevaron a cabo un estudio batimétrico, magnético y gravimétrico en la península de Punta Banda y encontraron un conjunto de fallas normales que cruzan la península en dirección N-S. González-Serrano (1977) interpretó varios perfiles gravimétricos y magnéticos y describió algunas de las fallas activas en la bahía. Wong (1980), mediante sismología de reflexión, realizó una configuración de la Bahía de Todos Santos y parte del borde continental interior. González y Suárez (1984) analizaron un enjambre sísmico localizado fuera de la costa y establecieron que tal actividad provenía de una nueva rama de la falla de Agua Blanca dentro de la bahía de Ensenada. Pou (1982), Quintanilla-Montoya (1984) y Quintanilla-Montoya y Suárez-Vidal (1992) describieron la geología estructural de la isla sur de Todos Santos y determinaron la relación entre el fallamiento de la isla y las principales fallas localizadas en el borde continental. Aunque todos estos estudios describen la mayoría de los aspectos estructurales relevantes dentro de la Planicie Costera de Todos Santos, no existe un modelo tectónico que describa cómo, cuándo y bajo qué régimen tectónico se desarrolló ésta. Asimismo, si el área sigue activa, es necesario establecer el peligro geológico y riesgo sísmico.

En este estudio se presentan los resultados del procesamiento de los datos magnéticos y gravimétricos de la literatura disponible (tesis de licenciatura y maestría, artículos profesionales, etc.), empleando la nueva técnica de inversión 
normal faults that are cross-cutting the peninsula in a N-S direction. González-Serrano (1977) interpreted several gravity and magnetic profiles and described some of the active faults within the bay. Wong (1980), using reflection seismology, made a configuration of Todos Santos Bay and part of the inner continental borderland. González and Suárez (1984) closely analyzed a seismic swarm located offshore and established that such activity was produced by a new branch of the Agua Blanca fault within Ensenada Bay. Pou (1982), QuintanillaMontoya (1984) and Quintanilla-Montoya and Suárez-Vidal (1992) described the structural geology of the southern Todos Santos island and determined the relationship between the faulting at the island and the major faults located in the continental borderland. Although these studies describe most of the relevant structural features found within the Todos Santos Coastal Plain, there is no tectonic model that describes how, when and under what tectonic regime the coastal plain was developed. Further, if the area is still active, the geologic hazard and seismic risk need to be established.

We present the results of processing the magnetic and gravity data from the existent literature (bachelor and master theses, professional papers, etc.), applying the Gallardo et al. (2003) new inversion technique of joint gravity and magnetic data from 3-D geologic structures, although the main objective here is not to describe the method. We demonstrate that this technique, when applied to an area such as the Todos Santos Coastal Plain, results in a map that describes the structural pattern and creates a tectonic model for the region. By comparing our 3-D model with the previous 2-D model, new structural features were obtained.

\section{Regional geology}

The present topography of the Baja California peninsula closely reflects its geologic history and structure. The area can be subdivided into four regions of distinct topographic character. These, in turn, can be subdivided into geomorphic provinces.

On the west coast, a line approximating the Santillán and Barrera line separates the coastal terraces and continental borderland areas from the plateaus of the central peninsula (Gastil et al., 1975). To the north, between the Santillán and Barrera line and the peninsular plateaus, is a region of rugged topography developed primarily on prebatholithic volcanic rocks. This topographic region continues into California (USA).

In Baja California, six distinct geomorphologic provinces are well defined: Pacific Coastal, Coastal Mountain, Northern Highland Plateau, Highland Valley, Southern Highland Plateau and Gulf of California. The Ensenada region is part of the Pacific Coastal Province and is included within the Santo Tomás Block/Todos Santos Coastal Plain, but it is also considered part of the Coastal Mountain Province, known as the Ensenada Block (Gastil et al., 1975).

The Ensenada Block is characterized by a rough topography and it extends from the Guadalupe Valley to the Agua

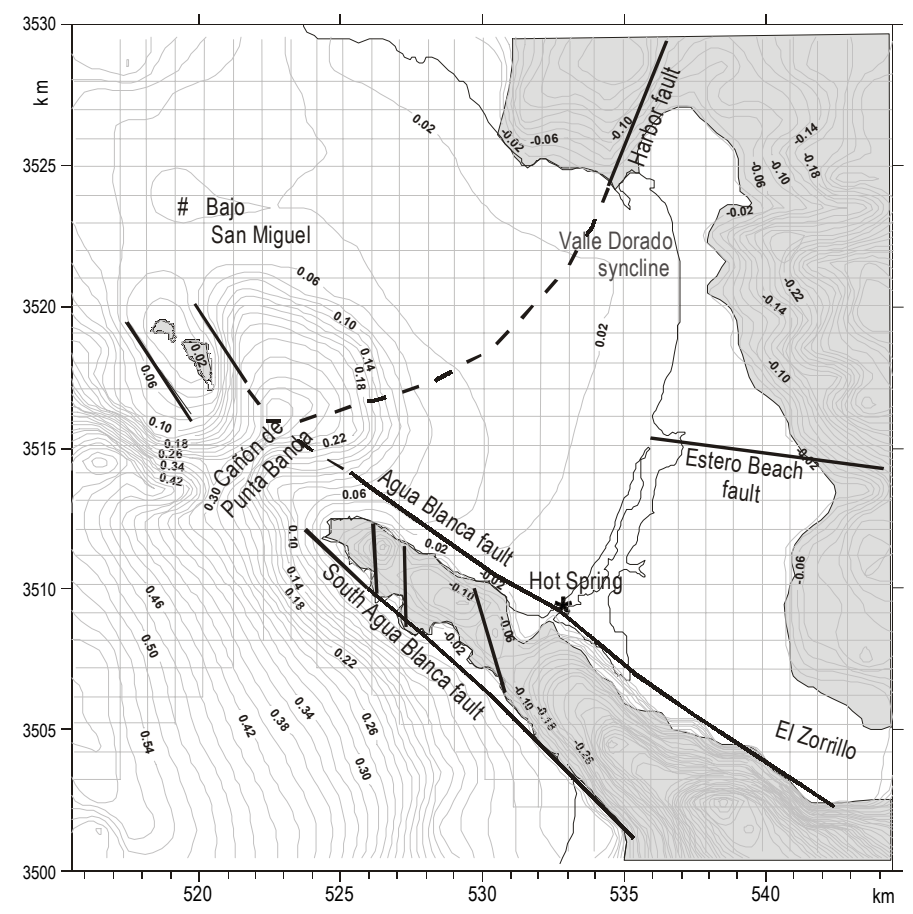

Figure 2. Previous geological model. Lines are faults and dashed lines are hypothetical faults. The grid lines represent the positions of the vertical prisms used for the inversion.Topographic and bathymetric curves are represented every $20 \mathrm{~m}$. Positive values are above sea level.

Figura 2. Modelo geológico previo. Las líneas representan las fallas y las líneas quebradas, las fallas hipotéticas. Las líneas de la cuadrícula representan las posiciones de los prismas verticales utilizados para la inversión. Las curvas topográficas y batimétricas se representan cada $20 \mathrm{~m}$. Los valores positivos son por encima del nivel del mar.

conjunta de datos gravimétricos y magnéticos de estructuras geológicas tridimensionales de Gallardo et al. (2003), aunque el objetivo principal no es describir el método. Se muestra que cuando se aplica esta técnica a un área como la Planicie Costera de Todos Santos, se obtiene un mapa que describe el patrón estructural así como un modelo tectónico para la región. Al comparar nuestro modelo tridimensional con el bidimensional previo, se establecen nuevos rasgos estructurales.

\section{Geología regional}

La topografía actual de la península de Baja California refleja su historia y estructura geológica. El área se puede subdividir en cuatro regiones de carácter topográfico distinto $\mathrm{y}$, a su vez, éstas se pueden subdividir en provincias geomórficas.

En la costa oeste, una línea próxima a la línea de Santillán y Barrera separa las terrazas costeras y áreas del borde continental de las mesetas de la península central (Gastil et al., 1975). Al norte, entre la línea de Santillán y Barrera y las mesetas peninsulares, se encuentra una región de topografía accidentada, desarrollada principalmente sobre rocas volcánicas prebatolíticas. Esta región topográfica se extiende hasta California (EUA). 
Blanca fault in the south. To the east, a series of high peaks mark the eastern edge of this block. The area is dissected by the west-flowing Guadalupe River, Santa Clara River, Cañón de la Chispa and Arroyo Santo Tomás, which cut gorges as much as $1000 \mathrm{~m}$ deep (Gastil et al., 1975). The Ensenada Block stands $500 \mathrm{~m}$ above sea level (on average), giving little evidence of a pre-existing Early Tertiary surface. A lag deposit, the remnant of a fluvial conglomerate, is scattered over a $400 \mathrm{~m}$ high plateau in the northwestern corner of the block.

The Todos Santos Coastal Plain covers an area of $150 \mathrm{~km}^{2}$ occupied by the city of Ensenada, Maneadero Valley (Ejido Sánchez Taboada) and Todos Santos Bay. The area is a halfgraben controlled by the Agua Blanca fault as the southern limit. This half-graben is filled with more than $2000 \mathrm{~m}$ of sediments of unknown age. The mesas to the north do not pass beneath these deposits but stand as high bluffs that were once wave-battered headlands (Gastil et al., 1975).

The Todos Santos Coastal Plain is surrounded by the Early Cretaceous (Aptian-Albian) Alisitos Formation, composed of andesites and pyroclastic material. Allison (1955) described the Alisitos Formation as a sequence of $1790 \mathrm{~m}$ of thinly bedded (including diorite sills) tuffs. On top of this, there are $1500 \mathrm{~m}$ of mudstones and, in lesser proportion, some sandstones. Resting over the mudstone there are more than $2000 \mathrm{~m}$ of pyroclastic and epiclastic intermediate volcanic rocks and porphyritic andesite. South of the Agua Blanca fault, the Alisitos Formation terminates with a sequence of biohermal limestones and intercalated beds of pyroclastic material. North of the Agua Blanca fault, the calcareous sedimentary sequence is absent, hence there is no fauna-fossil that can be used for accurate age control of the Early Cretaceous rocks. The ENE part of the Todos Santos Coastal Plain is bound by a pluton of tonalite-granodiorite 120 to $110 \mathrm{Ma}$ from the peninsular batholith (Ortega et al., 1997). To the west-northwest the intrusive rocks are in contact with the Alisitos Andesite that outcrops in the Chapultepec Hills, as well as to the north of them. North of the city of Ensenada, and in the El Sauzal area, the Alisitos Formation is in contact with the Late Cretaceous Rosario Formation. This formation is well represented along the southwestern part of California and northwesterly Baja California, and it is characterized by a thick sequence of clastic material wedged against the Alisitos Formation.

The Rosario Formation represents a continental to deep water marine facies that was deposited along the margin of a Great Valley type fore-arc basin. Sediments were derived from rugged eastern highlands formed by uplifted peninsular ranges, granitic-metamorphic terrain (arc system). In the Ensenada region, the general Rosario stratigraphy reflects an initial phase of non-marine conditions, followed by the widespread marine incursion of the last major eustatic sea-level rise of the Cretaceous.

The Punta Banda peninsula closes the south side of Ensenada Bay. This peninsula rises several hundred meters above sea level and lithologically is formed by the Early Cretaceous Alisitos Formation andesites. In the westerly two-thirds
En Baja California hay seis provincias geomorfológicas bien definidas: la costa Pacífica, la sierra costera, la meseta alta norteña, el valle alto, la meseta alta sureña y el Golfo de California. La región de Ensenada forma parte de la Provincia de la Costa Pacífica y se incluye dentro del Bloque de Santo Tomás/Planicie Costera de Todos Santos, aunque también se considera parte de la Provincia de la Sierra Costera conocida como el Bloque de Ensenada (Gastil et al., 1975).

El Bloque de Ensenada se caracteriza por su topografía accidentada y se extiende del Valle de Guadalupe a la falla de Agua Blanca en el sur. Al este, una serie de picos altos marca el límite oriental de este bloque. El área es disectada por el Río Guadalupe que fluye al oeste, el Río Santa Clara, el Cañón de la Chispa y el Arroyo Santo Tomás, los cuales forman cañadas de hasta $1000 \mathrm{~m}$ de profundidad (Gastil et al., 1975). El Bloque de Ensenada se encuentra a $500 \mathrm{~m}$ sobre el nivel del mar (en promedio), con poca evidencia de una superficie preexistente del Terciario temprano. Un depósito remanente de un conglomerado fluvial se encuentra esparcido sobre una meseta de $400 \mathrm{~m}$ de altura en la esquina noroccidental del bloque.

La Planicie Costera de Todos Santos cubre un área de $150 \mathrm{~km}^{2}$ ocupada por la ciudad de Ensenada, el Valle de Maneadero y la Bahía de Todos Santos. El área es un semigraben controlado por la falla de Agua Blanca como límite sur. El semigraben está lleno de $2000 \mathrm{~m}$ de sedimentos de edad desconocida. Las mesas al norte no pasan debajo de estos depósitos pero aparecen como riscos que alguna vez fueron cabos abatidos por las olas (Gastil et al., 1975).

La Planicie Costera de Todos Santos está rodeada por la Formación Alisitos del Cretácico temprano (Aptiano-Albiano), compuesta de andesitas y material piroclástico. Allison (1955) describe a la Formación Alisitos como una secuencia de $1790 \mathrm{~m}$ de estratos delgados (incluyendo sills dioríticos) de tobas. Por encima, hay $1500 \mathrm{~m}$ de lodos (arcillas) y, en menor proporción, areniscas. Descansando sobre los lodos hay más de $2000 \mathrm{~m}$ de roca volcánica piroclástica y epiclástica intermedia y andesita porfirítica. Al sur de la falla de Agua Blanca, la Formación Alisitos culmina con una secuencia de caliza biohermal y capas intercaladas de material piroclástico. Al norte de la falla de Agua Blanca está ausente la secuencia sedimentaria calcárea; por tanto, no hay una fauna fósil que pueda usarse para precisar la edad de las rocas cretácicas tempranas. La parte al ENE de la Planicie Costera de Todos Santos está delimitada por un plutón de tonalita-granodiorita de 120 a 110 Ma del batolito peninsular (Ortega et al., 1997). Al oestenoroeste, las rocas intrusivas están en contacto con la Andesita Alisitos que aflora en las colinas de Chapultepec, así como al norte de ellas. Al norte de la ciudad de Ensenada y en el área de El Sauzal, la Formación Alisitos está en contacto con la Formación Rosario del Cretácico tardío. Esta formación está bien representada en el suroeste de California y noroeste de Baja California y se caracteriza por una secuencia gruesa de material clástico acuñada contra la Formación Alisitos.

La Formación Rosario representa facies continentales a agua marina profunda que se depositó a lo largo de una margen 
of the peninsula, the andesites are in contact with the Late Cretaceous Rosario Formation. One of the fewest outcrops of the rudist exists in this area, known as Coralliochama orcutti, which forms a bank developed within the lowest sandstone unit, and represents a rudist reef in a wave-washed cliff and rocky headland (Ross, 1981). The city of Ensenada and the rural area to the south are located over a plain filled with sediments eroded from the peninsular ranges and on top of this there is the Quaternary alluvial material. All the above lithological units are distributed around Ensenada Bay (mainland and in the continental borderland) and play an important role that has to be considered in a structural and tectonics model.

\section{Main structural element}

The major structural element within the Todos Santos Coastal Plain is the Agua Blanca fault, which is a dextral strike-slip fault oriented $\mathrm{N} 68^{\circ}-70^{\circ} \mathrm{W}$, oblique, almost perpendicular to the general strike of the San Andreas-Gulf of California fault system. This fault extends for more than $140 \mathrm{~km}$ from the San Matías pass, in the east, to Ensenada Bay, which continues offshore. The Agua Blanca fault is one of the active faults in the northern Baja California region. It can be traced as a single structure from the San Matías pass to the Santo Tomás valley (Allen et al., 1960; Rockwell et al., 1987; Ortega, 1988; Suárez et al., 1991). From this valley to the west, the fault branches in two segments that bound the Punta Banda peninsula along the south and northern flanks (fig. 2). In the northern sector along Ejido Sánchez Taboada (Maneadero), the fault has a transition from its dextral strike-slip movement to a normal fault behavior, with significant vertical displacement, and it forms the southwest limit of the half-graben that characterizes the Todos Santos Plain (Gastil et al., 1975). The Agua Blanca North fault passes offshore along the north side of Punta Banda Ridge, where it marks the steeply dipping contact between basement rocks of the peninsula, including the Todos Santos islands, and the thick fill sediments in Todos Santos Bay. The fault makes a sharp turn from nearly $\mathrm{N} 70^{\circ} \mathrm{W}$ to a more northerly $\mathrm{N} 25^{\circ}-30^{\circ} \mathrm{W}$ strike east of the Todos Santos islands (Legg et al., 1991). Along the north branch of the Agua Blanca fault there are several hot springs originated by deep circulation of metheoric water. The NW hot spring is located on the beach at the shore line where the fault intercepts the sand barrier at Estero Beach (Hummel, 1972).

The other major structural element in the Ensenada area is a left lateral strike-slip fault, oriented almost $\mathrm{N}-\mathrm{S}$ and located just north $(600 \mathrm{~m})$ of the entrance to the harbor; GonzálezSerrano (1977) has hypothesized that it extends through the sea to connect with the Agua Blanca fault (fig. 2). The Agua Blanca fault has also been traced with reflection seismology (Wong, 1980; Wong et al., 1987). In the area known as Valle Dorado (fig. 2), the andesites from the Alisitos Formation are deformed developing a syncline oriented in $\mathrm{E}-\mathrm{W}$ direction. To the south, the Ejido Sánchez Taboada (Maneadero Valley, fig. 1) is located in a half-graben whose southern limit is the tipo Great-Valley en cuenca de ante-arco. Los sedimentos se derivaron de montañas escarpadas orientales formadas por sierras peninsulares levantadas, terreno granítico-metamórfico (sistema de arco). En la región de Ensenada, la estratigrafía general de la Formación Rosario refleja una fase inicial de condiciones no marinas, seguida por la extensa incursión marina de la última gran elevación eustática del nivel del mar en el Cretácico.

La península de Punta Banda limita el lado sur de la Bahía de Ensenada. Esta península se eleva varios cientos de metros por arriba del nivel del mar y litológicamente está formada por las andesitas de la Formación Alisitos del Cretácico temprano. En las dos terceras partes occidentales de la península, las andesitas están en contacto con la Formación Rosario del Cretácico tardío. En esta área se encuentra uno de los pocos afloramientos del rudista conocido como Coralliochama orcutii, el cual forma un banco desarrollado dentro de la unidad de arenisca inferior y representa un arrecife rudista en un risco bañado por las olas y en zona montañosa (Ross, 1981). La ciudad de Ensenada y la zona rural al sur se localizan sobre una planicie llena de sedimentos erosionados de las sierras peninsulares, sobre la cual hay material aluvial del Cuaternario. Todas estas unidades litológicas están distribuidas alrededor de la Bahía de Ensenada (continente y borde continental) y juegan un papel importante que debe considerarse en un modelo estructural y tectónico.

\section{Principal elemento estructural}

El principal elemento estructural dentro de la Planicie Costera de Todos Santos es la falla de Agua Blanca, la cual es una estructura de rumbo derecha con orientación $\mathrm{N} 68^{\circ}-70^{\circ} \mathrm{W}$, oblicua, casi perpendicular al rumbo general del sistema de falla San Andrés-Golfo de California. Esta falla se extiende por más de $140 \mathrm{~km}$ desde el Paso de San Matías, al este, hasta la Bahía de Ensenada donde continúa mar adentro. La falla de Agua Blanca es una de las fallas más activas en el norte de Baja California. Consiste en una sola estructura desde el Paso de San Matías hasta el Valle de Santo Tomás (Allen et al., 1960; Rockwell et al., 1987; Ortega, 1988; Suárez et al., 1991), donde se divide hacia el oeste en dos segmentos que limitan el sur y el norte de la península de Punta Banda (fig. 2). En el segmento norte a lo largo del Ejido Sánchez Taboada (Maneadero), la falla tiene una transición de movimientos laterales a un comportamiento de falla normal, con desplazamiento vertical significativo, y forma el límite suroeste del semigraben que caracteriza la Planicie de Todos Santos (Gastil et al., 1975). La falla norte de Agua Blanca se introduce fuera de la costa por el lado norte de la cordillera de Punta Banda, donde marca el contacto muy inclinado entre las rocas de basamento de la península, incluyendo las islas Todos Santos, y los densos sedimentos en la Bahía de Todos Santos. La falla cambia abruptamente de casi $N 70^{\circ} \mathrm{W}$ a un rumbo de $\mathrm{N} 25^{\circ}-30^{\circ} \mathrm{W}$ al este de las islas Todos Santos (Legg et al., 1991). Sobre el brazo norte de la falla de Agua Blanca se encuentran varios 
Agua Blanca fault and its northern limit is the Estero Beach fault (González and Suárez, 1984) (fig. 2). It extends along the Cañón de San Carlos in a westerly direction and continues offshore just at the mouth of the Estero Beach coastal lagoon (fig. 1).

Within Todos Santos Bay there are two main morphological elements that are well expressed in the bathymetry. The Cañón de Punta Banda (fig. 2) is a typical structure with a bowl-shaped head, located within a large, coastal embayment (Ensenada Bay). This shape may be the result of headward erosion by large scale slumping and sliding of unconsolidated sediments. The Cañón de Punta Banda necks downstream, passing through a narrow gorge cut into older uplifted bedrock that is sub-aerially exposed at Punta Banda and Todos Santos islands (Gastil et al., 1975; Legg, 1985). The expression of sinuousity varies from sharp, almost right-angle turns, implying fault or joint control, to smooth meanders, similar to those seen along many rivers (Reineck and Singh, 1980, p. 260). A significant sharp bend in the Cañón de Punta Banda west of the tip of the Punta Banda peninsula can be evidence of $4 \mathrm{~km}$ of right lateral offset associated with the branch of the Agua Blanca fault. The other morphological element is the Bajo de San Miguel (San Miguel topographic low). This bathymetric elevation is located between the Todos Santos islands and Punta San Miguel (figs. 1, 2) and may correspond to the northwest limit of the Ensenada half-graben or to a local uplift of the Cretaceous basement.

\section{Data description}

The geophysical data used in the present work come from different gravity and magnetic surveys made between 1977 and 2000. The land gravity data come from Vázquez (1980), Cruz (1986) and Aguero (1986) (fig. 3). The marine gravity data come from González-Serrano (1977) and the marine magnetic data are from González-Fernández et al. (2000). Aeromagnetic data are from Consejo de Recursos Naturales No Renovable (1962) and land magnetic data from González-Fernández et al. (2000) (fig. 3). All data sets needed different processes to homogenize them. In figure $3 \mathrm{a}$ and $3 \mathrm{c}$ we present the gravity and magnetic data used in this project. Although each data set was recorded at a different altitude, these were plotted together as they are only a graphical representation and the inversion process takes into account the differences in altitude.

The available gravity data cover the Maneadero Valley and the coastline from Maneadero in the south to San Miguel in the north. The measurements were made using a Worden gravity meter from San Diego State University (Vázquez, 1980), with a precision of $0.1 \mathrm{mgal}$. The common corrections made to gravity data were the correction by latitude shift, Bouguer slab and topography. The marine gravity survey was performed with a Lacoste Romberg S-42 from Oregon State University, installed on board the Mexican Navy O/V DM-20. The data published by González-Serrano (1977) were corrected by horizontal and vertical acceleration, cross-coupling and latitude shift. Also, a regional was subtracted. manantiales termales resultado de la circulación profunda de agua meteórica. El manantial termal NW se localiza sobre la playa en la línea de costa donde la falla intercepta la barra de arena de Estero Beach (Hummel, 1972).

El otro elemento estructural importante en el área de Ensenada es la falla de rumbo izquierdo, orientada casi $\mathrm{N}-\mathrm{S}$ y localizada al norte $(600 \mathrm{~m})$ de la entrada al puerto; según la hipótesis de González-Serrano (1977), ésta se extiende en el mar para conectarse con la falla de Agua Blanca (fig. 2). La falla de Agua Blanca también ha sido trazada mediante sismología de reflexión (Wong, 1980; Wong et al., 1987). En la zona conocida como Valle Dorado (fig. 2), las andesitas de la Formación Alisitos se encuentran deformadas desarrollando una orientación sinclinal en dirección E-W. Al sur, el Ejido Sánchez Taboada (Valle de Maneadero, fig. 1) se localiza en un semigraben cuyo límite sur es la falla de Agua Blanca y su límite norte es la falla de Estero Beach (González y Suárez, 1984) (fig. 2). Se extiende por el Cañón de San Carlos en dirección oeste y continúa mar adentro justo en la boca de la laguna costera de Estero Beach (fig. 1).

Dentro de la Bahía de Todos Santos se encuentran elementos morfológicos principales bien expresados en la batimetría. El Cañón de Punta Banda (fig. 2) es típico de un estructura en la que su cabeza tiene forma de cuenco, localizado dentro de una ensenada costera grande (Bahía de Ensenada). Esta forma puede ser resultado de erosión por el derrumbe y deslizamiento a gran escala de sedimentos no consolidados. El Cañón de Punta Banda se estrecha flujo abajo, pasando por una cañada angosta que corta un lecho de roca que está semiexpuesta al aire en Punta Banda e islas Todos Santos (Gastil et al., 1975; Legg, 1985). La expresión de sinuosidad varía desde curvas muy cerradas de casi un ángulo recto, lo que implica control por falla a meandros tranquilos, similares a los de muchos ríos (Reineck y Singh, 1980, p. 260). Una curva cerrada importante en el Cañón de Punta Banda al oeste de la punta de la península de Punta Banda puede ser evidencia de $4 \mathrm{~km}$ de separación a la derecha asociada con el brazo de la falla de Agua Blanca. El otro elemento morfológico es el Bajo de San Miguel. Esta elevación batimétrica se localiza entre las islas Todos Santos y Punta San Miguel (figs. 1, 2) y puede corresponder al límite noroeste del semigraben de Ensenada o a la elevación del basamento cretácico.

\section{Descripción de los datos}

Los datos geofísicos utilizados en este trabajo provienen de diferentes estudios gravimétricos y magnéticos realizados entre 1977 y 2000. Los datos gravimétricos terrestres fueron tomados de Vázquez (1980), Cruz (1986) y Aguero (1986) (fig. 3). Los datos de gravimetría marina se obtuvieron de GonzálezSerrano (1977) y los de magnética marina de GonzálezFernández et al. (2000). Los datos aeromagnéticos son del Consejo de Recursos Naturales No Renovables (1962) y los magnéticos terrestres de González-Fernández et al. (2000) (fig. 3). Se requirieron diferentes procesos para homogeneizar 
a
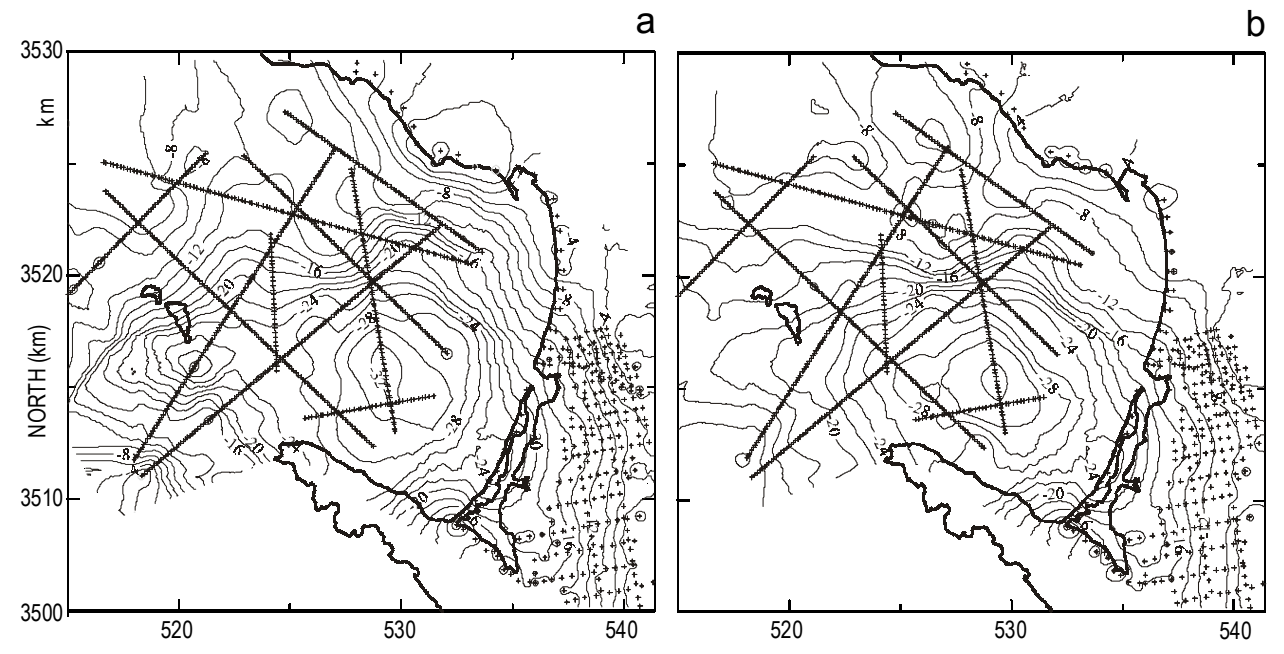

C
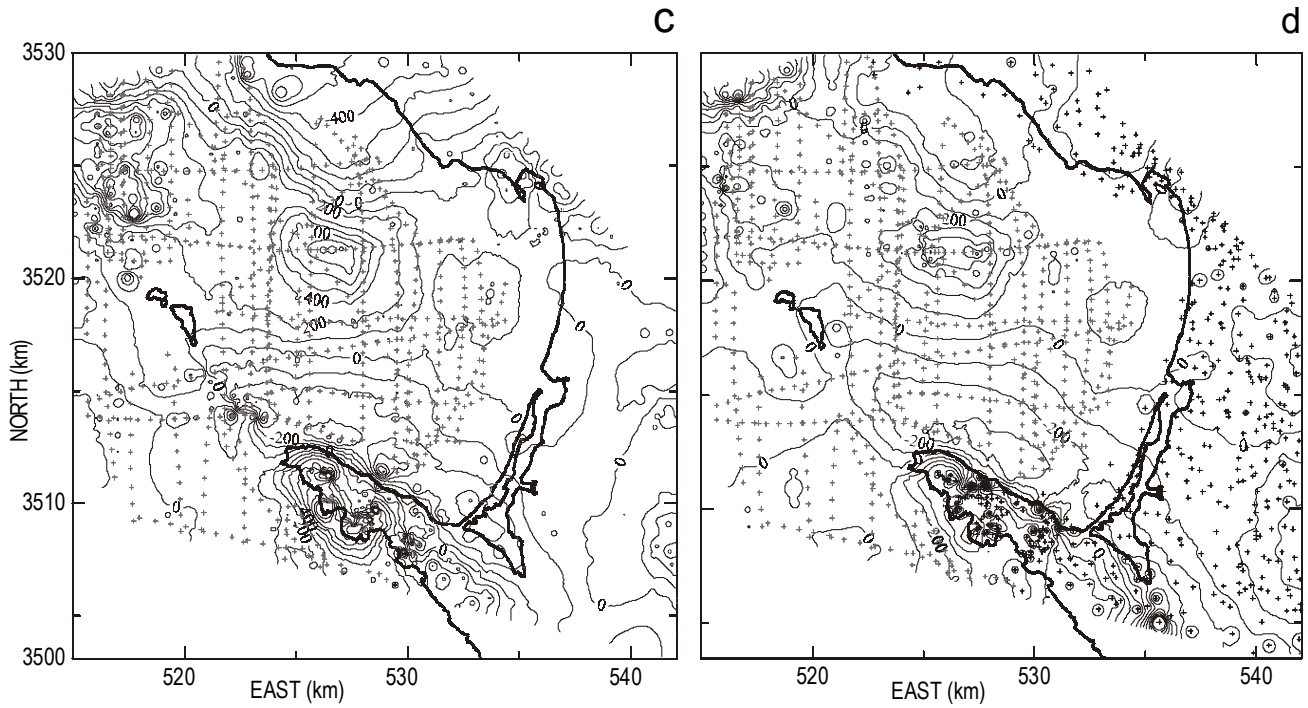

Figure 3. (a) Gravity observations. (b) Gravity response of the final model. (c) Magnetic observations. (d) Magnetic response of the best model. Continuous lines are transects and symbols are measurements.

Figura 3. (a) Observaciones gravimétricas. (b) Respuesta gravimétrica al modelo final. (c) Observaciones magnéticas. (d) Respuesta magnética al mejor modelo. Las líneas continuas son transectos y los símbolos son mediciones.

The magnetic data cover the onshore area from Punta Banda to Maneadero, Ensenada city and toward San Miguel (fig. 3c). The marine survey covers the bay very well, even outside the deep channel and the shallow waters of San Miguel in the NW of the bay. The bathymetry and marine magnetic data were taken by González-Fernández et al. (2000) with a dual frequency echosounder and magnetometer installed on the O/V Francisco de Ulloa owned by the Centro de Investigación Científica y de Educación Superior de Ensenada (CICESE). The land equipment consisted of two EG\&G magnetometers. The data from González-Fernández et al. (2000) and Consejo de Recursos Naturales No Renovables (1962) were corrected by diurnal variation and IGRF value. Measurements were plotted together regardless of the differences in altitude, because the inversion process takes this into consideration. The gravity anomaly shows a high close to San Miguel and a low close to todos los conjuntos de datos, y en la figura $3 \mathrm{a}$ y $3 \mathrm{c}$ se presentan los datos gravimétricos y magnéticos usados en este estudio. Aunque cada conjunto de datos fue registrado a diferente altura, se graficaron juntos ya que son sólo una representación gráfica y el proceso de inversión considera las diferencias de altitud.

Los datos gravimétricos disponibles cubren el Valle de Maneadero y la línea de costa desde Maneadero, en el sur, hasta San Miguel, en el norte. Las mediciones fueron realizadas con un gravímetro marca Worden de la Universidad Estatal de San Diego (Vázquez, 1980), con una precisión de $0.1 \mathrm{mgal}$, y corregidas para desplazamiento latitudinal, anomalía de Bouguer y topografía. El estudio de gravimetría marina se llevó a cabo con un Lacoste Romberg S-42 de la Universidad Estatal de Oregon, instalado a bordo del B/O $D M-20$ de la Armada de México. Los datos publicados por 
the Agua Blanca fault, indicating less dense material or deeper basement. The magnetic anomaly shows the lowest values at the middle of the bay, indicating less magnetic material or deeper magnetic basement.

\section{Gravity and magnetic methodology}

To model the Todos Santos Coastal Plain, several assumptions were applied. The Gallardo et al. (2003) technique, which served as the basis, uses a grid of vertical prisms. The depth to the top of every prism (referred to as top topography) is fixed to the topography-bathymetry of the sedimentary sequence or to the basement that outcrops around the basin. The depth to each bottom prism is free (bottom topography) (fig. 2). The inversion process tries to fit automatically the bottom topography of the prisms with the boundary of the sedimentary basin with the basement using the gravity and magnetic data available as constraints. The resulting model takes into consideration the different altitude of every measurement and computes the model response at the same altitude for their comparison. It is not necessary to reduce the data to a flat level. The model is well constrained by the information from the exposed basement and by fitting the gravity and magnetic anomaly. A regularization is applied, consisting of the minimization of the second spatial derivatives from the bottom topography. This procedure will find the smoothest model that best fits the data, avoiding unnecessary and fictitious roughness in the model due to the random error added when the measurements were taken.

This algorithm also estimates the density variable with depth and the magnetization vector given by the director cosines. From these director cosines it is possible to compute the magnetization magnitude, inclination and declination. One density function and constant magnetization contrast is allowed. We define the contrast as the difference between the sediments and the basement in the density function or the magnetization. In terms of inversion, the problem is non-linear for the determination of prism depths. A rearrangement of the equations was needed in order to allow equality and inequality constraints in every variable by means of quadratic programming. This advantage gave us the opportunity to introduce additional information, such as exploratory wells or exposed basement, or to constrain some parameters into an interval, according to a previous hypothetical model. The program minimizes the error between the data and the response of the model that is obtained iteratively until it arrives at the best fit. It also minimizes the spatial derivatives of bottom depths of the prisms.

The Todos Santos Coastal Plain data require a versatile program such as that developed by Gallardo et al. (2003). The area of study is located between kilometers 516 and 544 UTM in W-E direction and 3501 and 3529 UTM in S-N direction. The prism grid consists of $28 \times 28=784$ prisms, with a plane section of $1 \times 1 \mathrm{~km}$, each one with a total area of $784 \mathrm{~km}^{2}$ (fig. 2). The depth to the top of every prism was fixed with the
González-Serrano (1977) fueron corregidos por aceleración horizontal y vertical, interacoplamiento y desplazamiento latitudinal. Asimismo, se restó el regional.

Los datos magnéticos cubren el área costera de Punta Banda a Maneadero, la ciudad de Ensenada y hacia San Miguel (fig. 3c). El estudio marino cubre muy bien la bahía, inclusive afuera del canal profundo y las aguas someras de San Miguel en el NW de la bahía. La batimetría y los datos magnéticos marinos fueron registrados por González-Fernández et al. (2000) con una ecosonda de doble frecuencia y un magnetómetro instalados a bordo del B/O Francisco de Ulloa del Centro de Investigación Científica y de Educación Superior de Ensenada (CICESE). El equipo terrestre consiste en dos magnetómetros EG\&G. Los datos de González-Fernández et al. (2000) y el Consejo de Recursos Naturales No Renovables (1962) fueron corregidos por variación diurna y valor de IGRF. Se graficaron juntas las mediciones independientemente de la altitud ya que el proceso de inversión toma esto en consideración. La anomalía gravitacional muestra un alto cerca de San Miguel y un bajo cerca de la falla de Agua Blanca, lo que indica material menos denso o un basamento más profundo. $\mathrm{La}$ anomalía magnética muestra los valores más bajos en el centro de la bahía, lo que indica menos material magnético o un basamento magnético más profundo.

\section{Metodología gravimétrica y magnética}

Se aplicaron varios supuestos en la modelación de la Planicie Costera de Todos Santos. La técnica de Gallardo et al. (2003), que sirvió como base, utiliza una retícula de prismas verticales. La profundidad a lo alto de cada prisma (esto es, la topografía superior) es fijada a la topografía-batimetría de la secuencia sedimentaria o al basamento que aflora alrededor de la cuenca. La profundidad a cada prisma inferior es libre (topografía inferior) (fig. 2). El proceso de inversión trata de ajustar automáticamente la topografía inferior de los prismas con el contorno de la cuenca sedimentaria con el basamento usando los datos gravimétricos y magnéticos disponibles como restricciones. El modelo resultante toma en consideración la diferente altura de cada medida y calcula la respuesta del modelo a la misma altitud para su comparación. No es necesario reducir los datos a un plano. El modelo está bien delimitado por la información del basamento expuesto y por el ajuste de la anomalía gravitacional y la magnética. Se aplica una regularización, que consiste en minimizar las segundas derivadas espaciales de la topografía del fondo. Este procedimiento encontrará el modelo más uniforme que mejor se ajuste a los datos, evitando asperezas innecesarias y ficticias en el modelo debido al error aleatorio introducido cuando se tomaron las mediciones.

Este algoritmo también estima la variable de densidad con profundidad y el vector de magnetización dado por los cosenos directores. Con estos cosenos de dirección es posible calcular la magnitud de magnetización, inclinación y declinación. Se permite un contraste de la función de densidad y magnetización constante, definiendo contraste como la diferencia entre 
corresponding topography or bathymetry. The prisms located in the exposed basement were fixed following the topography and taken out automatically from the inversion, corresponding to the shaded area in figure 2 .

The initial model for bottom depths was a constant basement depth of $500 \mathrm{~m}$. The density was supposed $2.6 \mathrm{~g} \mathrm{~cm}^{-3}$ for granites and $1.6 \mathrm{~g} \mathrm{~cm}^{-3}$ for sediments. We used an initial model with density contrast of $\Delta \rho(z)=\left(-1.0-0.05 z-0.05 z^{2}\right) \mathrm{g} \mathrm{cm}^{-3}$ and an initial magnetization contrast of $\Delta \mathbf{J}=-580 \mathrm{emu}$ $\left(\mathrm{I}=23^{\circ}, \mathrm{D}=6^{\circ}\right)$. After eleven iterations the best model was obtained. We assume that the depth estimated for every prism's bottom fits the topography of the granitic-andesitic basement under the bay and Maneadero Valley (fig. 4). The resulting density contrast was $\Delta \rho(z)=\left(-0.657+0.0 z+0.0 z^{2}\right) \mathrm{g} \mathrm{cm}^{-3}$ and a magnetization contrast of $\Delta \mathbf{J}=-203 \mathrm{emu}\left(\mathrm{I}=25^{\circ}\right.$, $\mathrm{D}=10^{\circ}$ ). The root mean square (RMS) error was $9.5 \%$. The model obtained was the smoothest model resulting from minimizing the second spatial derivatives of the bottom depths.

The algorithm allows variable altitude, so every gravity and magnetic measurement had $(x, y, z)$ coordinates. The sea has a gravity response but not magnetic. Based on what is known about the bathymetry, we extracted the gravity response of the sea to the gravity anomaly in order to manage just the contrast between the sediments and the granitic-andesitic basement. The gravity and magnetic response of the best model resembles the measurements very well (fig. $3 b, d$ ).

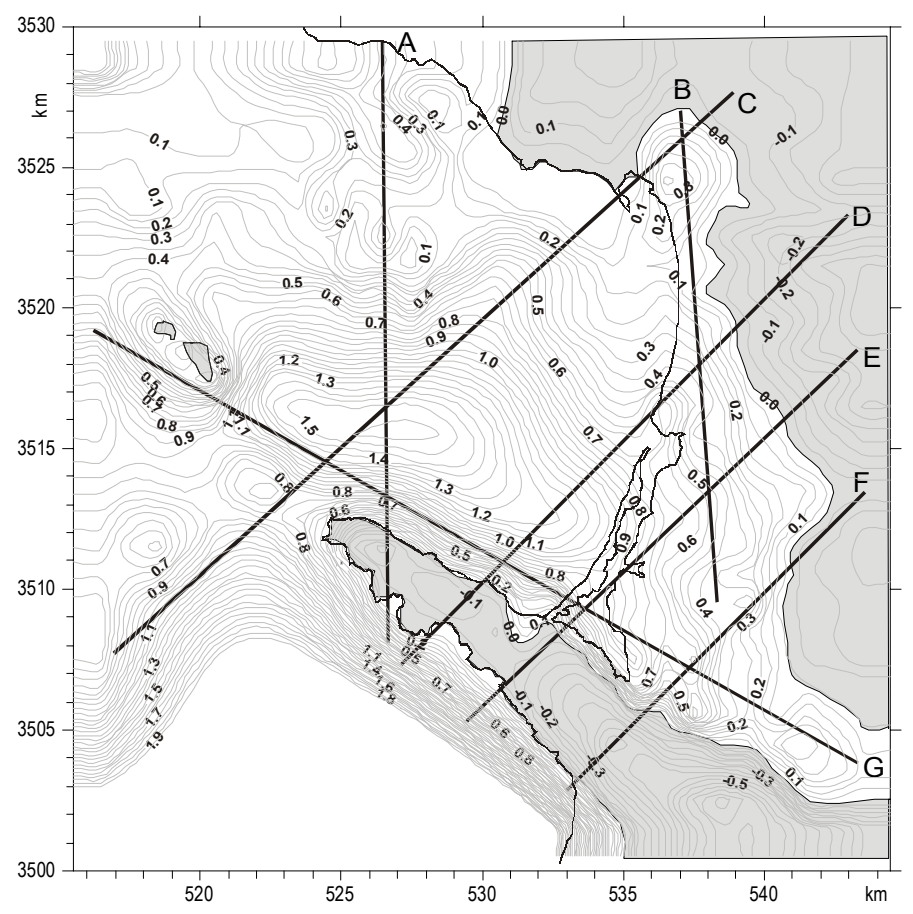

Figure 4. Three-dimensional model obtained after eleven iterations with a fit of $93 \%$. The straight lines represent cross-sections of the model. Level curves are every $50 \mathrm{~m}$.

Figura 4. Modelo tridimensional obtenido después de once iteraciones con un ajuste de $93 \%$. Las línes rectas representan las secciones transversales del modelo. Las curvas de nivel se muestran cada $50 \mathrm{~m}$. los sedimentos y el basamento en la función de densidad o la magnetización. En cuanto a inversión, el problema es no lineal para la determinación de las profundidades de los prismas. Fue necesario reordenar las ecuaciones para permitir restricciones de igualdad y desigualdad en cada variable mediante programación cuadrática. Esta ventaja permitió introducir información adicional, como pozos exploratorios o basamento expuesto, o restringir algunos parámetros dentro de un intervalo de acuerdo con un modelo hipotético previo. El programa minimiza el error entre los datos y la respuesta del modelo que se obtiene de forma iterativa hasta llegar al mejor ajuste, así como las derivadas espaciales de las profundidades inferiores de los prismas.

Los datos de la Planicie Costera de Todos Santos requieren de un programa versátil como el desarrollado por Gallardo et al. (2003). El área de estudio se localiza entre los kilómetros 516 y 544 UTM (Transversal Universal de Mercator) en dirección W-E y 3501 y 3529 UTM en dirección S-N. La retícula del prisma consiste en $28 \times 28=784$ prismas, con una sección plana de $1 \times 1 \mathrm{~km}$, cada una con un área total de $784 \mathrm{~km}^{2}$ (fig. 2). La profundidad a lo alto de cada prisma se ajustó con la topografía o batimetría correspondiente. Los prismas localizados en el basamento expuesto fueron ajustados siguiendo la topografía y quitados automáticamente de la inversión, lo que corresponde al área sombreada en la figura 2.

El modelo inicial de las profundidades inferiores fue una profundidad constante del basamento de $500 \mathrm{~m}$. La densidad se supuso de $2.6 \mathrm{~g} \mathrm{~cm}^{-3}$ para granitos y $1.6 \mathrm{~g} \mathrm{~cm}^{-3}$ para sedimentos. Se utilizó un modelo inicial con contraste de densidad de $\Delta \rho(z)=\left(-1.0-0.05 z-0.05 z^{2}\right) \mathrm{g} \mathrm{cm}^{-3}$ y un contraste inicial de magnetización de $\Delta \mathbf{J}=-580 \mathrm{emu}\left(\mathrm{I}=23^{\circ}, \mathrm{D}=6^{\circ}\right)$. El mejor modelo se obtuvo después de once iteraciones. Se supone que la profundidad estimada para el fondo de cada prisma se ajusta con la topografía del basamento granítico-andesítico de la bahía y el Valle de Maneadero (fig. 4). Se obtuvo un contraste de densidad de $\Delta \rho(z)=\left(-0.657+0.0 z+0.0 z^{2}\right) \mathrm{g} \mathrm{cm}^{-3}$ y un contraste de magnetización de $\Delta \mathbf{J}=-203 \mathrm{emu}\left(\mathrm{I}=25^{\circ}\right.$, $\mathrm{D}=10^{\circ}$ ). El error RMS (raíz cuadrada media) fue de $9.5 \%$. El modelo que se obtuvo fue el más uniforme resultante de minimizar las segundas derivadas espaciales de las profundidades inferiores.

El algoritmo permite una altitud variable; por tanto, cada medición gravimétrica y magnética tenía coordenadas $(x, y, z)$. El mar tiene una respuesta gravimétrica pero no magnética. Con base en lo que se conoce de la batimetría, se redujo la respuesta de gravedad del mar a la anomalía de gravedad para conseguir sólo el contraste entre los sedimentos y el basamento granítico-andesítico. La respuesta gravimétrica y magnética del mejor modelo es muy similar a las mediciones (fig. 3b, d).

\section{Modelo geológico}

El modelo geológico es sustentado por el modelo gravimétrico y magnético como la fuente común para ambos métodos. Al obtener el modelo más uniforme aparecen varias 


\section{Geological model}

The geological model is supported by the gravity and magnetic model as the common source for both methods. Several irregularities appear (fig. 4) when the smoothest model is obtained (i.e., we only obtained the irregularities needed by the data).

The gravity and magnetic responses of the estimated model are shown in figure $3 \mathrm{~b}$ and $3 \mathrm{~d}$, respectively. Comparing the observed and calculated anomalies, a good match is obtained (RMS $=93 \%$ for the whole data set).

The geological model shows a very well-developed basin with the deepest part located within the bay at $1650 \mathrm{~m}$ depth. Maneadero Valley is part of the same basin, which reaches its deepest part near the coast, $900 \mathrm{~m}$ close to the Punta Banda coastal lagoon. The basement is observed in the SE part of the area near El Zorrillo ranch (fig. 2). The same feature is observed under the city of Ensenada and corresponds to a welldeveloped basin with a maximum depth of $300 \mathrm{~m}$. Another small depression is observed where the Punta Banda coastal lagoon connects with the bay. The shape of the bay basin is not circular; it is almost an ellipse with the main axis in a NE direction. We may assume that this is the major tensional stress. Another relevant structural feature is located between the Punta Banda peninsula and Maneadero Valley where there is a large step that follows the trace of the Agua Blanca fault. The Punta Banda peninsula is flanked by the two well-known faults: Agua Blanca and Maximinos (also known as Agua Blanca South). This appears as a well-defined linear rise over the basin. Between the Punta Banda peninsula and Todos Santos islands there is another big step presumed to be a continuation of the Agua Blanca fault offshore and correlated with Cañón de Punta Banda.

Between Todos Santos islands and Punta San Miguel there is a rise of the basement that almost reaches sea level in the area known as Bajo San Miguel.

For a better understanding of the basin's shape, seven cross-sections in the SW-NE and N-S directions were constructed. Figure 4 is a gravimetric anomaly map and the lines within represent seven cross-sections. Their detail can be seen in figures 5 and 6 . All the cross-sections that are oriented in the $\mathrm{NE}-\mathrm{SW}$ direction are shown in figure 5, while the profiles oriented NW-SE and N-S are shown in figure 6.

Figure 5a corresponds to the location of cross-section $\mathbf{C}$ in figure 4. Close to the left (SW) side of profile $\mathbf{C}$ (between 521.5 and 524.5 UTM), a big promontory is seen that may correspond to the extension of the Punta Banda peninsula offshore, flanked by the Maximinos and North Agua Blanca faults, numbered $\mathbf{1 1}$ and $\mathbf{1 2}$ in figure 7, respectively. The deepest part of the basin is $1500 \mathrm{~m}$, rising gently in the NE direction (right side of the profile) before reaching the shore line. East of the shore line, another small basin is observed where the city of Ensenada is located.

Line D (figs. 4, 5b) extends from Punta Banda to Valle Dorado. In the SW part, the Punta Banda peninsula (left side of irregularidades cuando se obtiene el modelo más uniforme (fig. 4) (i.e., sólo obtuvimos las irregularidades que necesitaban los datos).

En la figura $3 \mathrm{~b}$ y $3 \mathrm{~d}$ se muestran las respuestas gravimétrica y magnética, respectivamente, del modelo estimado. La comparación de las anomalías observadas y calculadas muestra una buena similitud (RMS $=93 \%$ para todo el conjunto de datos).

El modelo geológico presenta una cuenca muy bien desarrollada con la parte más profunda, $1650 \mathrm{~m}$, en la bahía. El Valle de Maneadero forma parte de la misma cuenca y su parte más profunda, $900 \mathrm{~m}$, se encuentra cerca de la laguna costera de Punta Banda. El basamento se observa en la parte SE del área, cerca del rancho El Zorrillo (fig. 2); asimismo, éste se observa debajo de la ciudad de Ensenada y corresponde a una cuenca bien desarrollada con una profundad máxima de $300 \mathrm{~m}$. Otra depresión pequeña se encuentra donde la laguna costera de Punta Banda se conecta con la bahía. La forma de la cuenca de la bahía no es circular, sino casi una elipse con un eje principal en dirección NE. Se puede suponer que éste es el principal esfuerzo de tensión. Otro rasgo estructural importante se localiza entre la península de Punta Banda y el Valle de Maneadero, donde hay un escalón grande que sigue la huella de la falla de Agua Blanca. Existen dos fallas bien conocidas en ambos lados de la península de Punta Banda: Agua Blanca y Maximinos (también conocida como Agua Blanca Sur). Esto aparece como una elevación lineal bien definida sobre la
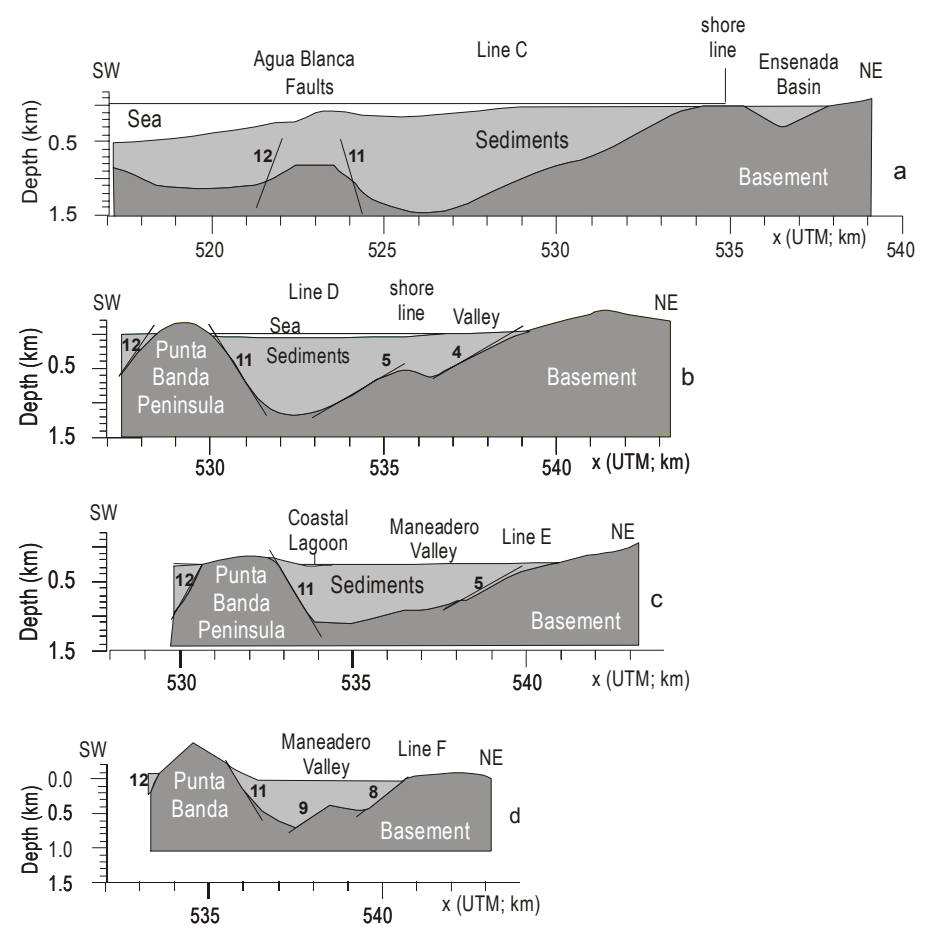

Figure 5. Cross-sections $\mathrm{C}, \mathrm{D}, \mathrm{E}$ and $\mathrm{F}$ of the three-dimensional model in SW-NE direction. The straight lines are proposed faults and are numbered for future reference.

Figure 5. Secciones transversales C, D, E y F del modelo tridimensional en dirección SW-NE. Las líneas rectas son fallas propuestas y se numeran para su discusión en el texto. 
the profile) is flanked by the Agua Blanca and Maximinos faults. In this profile, the deepest part of the bottom basin is at $1300 \mathrm{~m}$ and becomes shallower in the NE direction (right side of the profile). Despite the model being smoothed in the inversion, the data required two inflections before arriving at the hills around Valle Dorado. These small changes in the dip are interpreted as faults 5 and $\mathbf{4}$ (figs. 2, 7).

Line $\mathbf{E}$ and its associated profile (figs. 4, 5c) go from Punta Banda to Maneadero Valley. In the SW (left side of the profile) there is a persistent signature of the Punta Banda peninsula, as well as the Agua Blanca and Maximinos faults. In the same line $\mathbf{E}$, the basin can be seen to extend inland under Maneadero Valley where it reaches a maximum depth of $1100 \mathrm{~m}$, which is different than the $1700 \mathrm{~m}$ reported by Vázquez (1980). To the $\mathrm{NE}$ there is a change in the slope that may correspond to fault 5 in figure 7.

Line F (fig. 4) extends from Punta Banda to Arroyo San Carlos, passing through Maneadero Valley where the basin gets shallower: $700 \mathrm{~m}$, in contrast to the $900 \mathrm{~m}$ reported by Vázquez (1980). There are two changes in the slopes associated with faults 9 and $\mathbf{8}$ (figs. 5d, 7).

Line $\mathbf{G}$ runs (figs. 4, 6a) in NW-SE direction parallel to the Punta Banda peninsula, starting at Todos Santos islands and ending in El Zorrillo. In the NW part, the basement becomes shallower near the islands, then falls to the deepest part of the basin $(1400 \mathrm{~m})$ and turns complex between kilometers 527 and 533 UTM (fig. 7). This feature reflects the 3-D effects of the peninsula because the inversion was in 3-D. Between
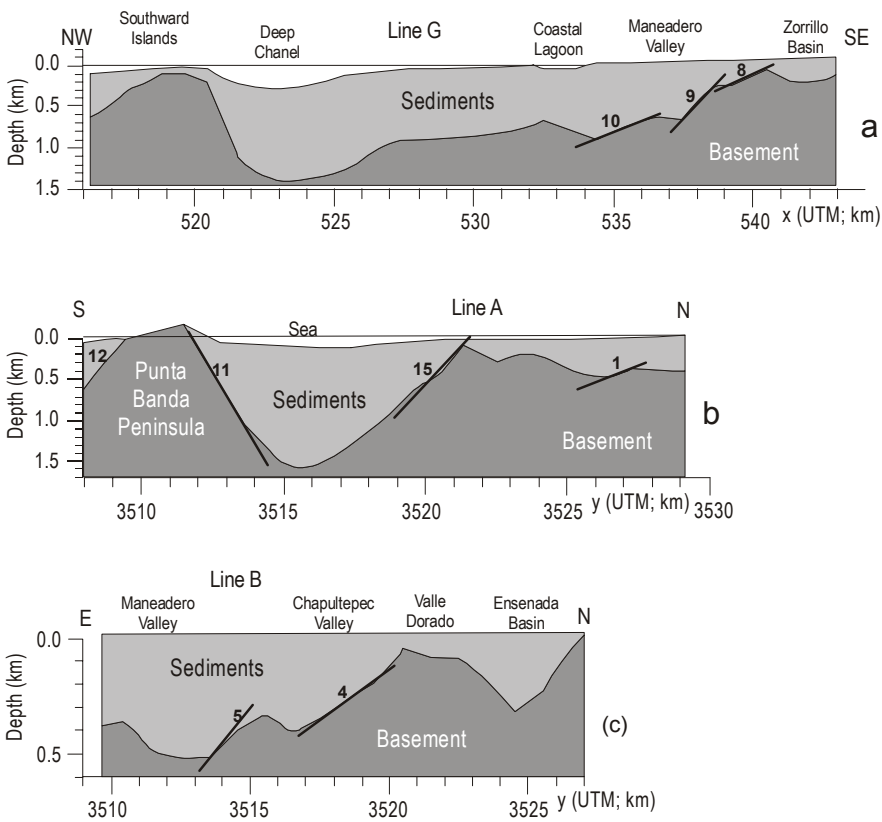

Figure 6. Cross-sections $\mathrm{G}, \mathrm{A}$ and $\mathrm{B}$ of the three-dimensional model. The straight lines are proposed faults and are numbered for discussion in text. Figura 6. Secciones transversales $G, A$ y $B$ del modelo tridimensional. Las líneas rectas son fallas propuestas y se numeran para su discusión en el texto. cuenca. Entre la península de Punta Banda y las islas Todos Santos se encuentra otro eslabón grande que supuestamente es una continuación de la falla de Agua Blanca hacia mar adentro, correlacionada con el Cañón de Punta Banda.

Entre las islas Todos Santos y Punta San Miguel, en el área conocida como Bajo San Miguel, hay una elevación del basamento que casi alcanza el nivel del mar.

Para una mejor comprensión de la forma de la cuenca, se construyeron siete secciones transversales en dirección $\mathrm{SW}-\mathrm{NE}$ y N-S. La figura 4 es un mapa de la anomalía gravimétrica y las líneas representan los siete cortes, cuyos detalles se pueden ver en las figuras 5 y 6 . En la figura 5 se presentan las secciones transversales que están orientadas en dirección NE-SW y en la figura 6 se presentan los perfiles orientados en dirección NW-SE y N-S.

La figura 5a corresponde a la localización de la sección transversal $\mathbf{C}$ en la figura 4. Cerca del lado izquierdo (SW) del pefil C (entre 521.5 y 524.5 UTM) se ve un promontorio grande, el cual puede asociarse con la extensión mar adentro de la península de Punta Banda, flanqueado por las fallas Maximinos y Agua Blanca Norte, numeradas 11 y 12 en la figura 7. La parte más profunda de la cuenca es de $1500 \mathrm{~m}$, elevándose ligeramente en dirección NE (lado derecho del perfil)

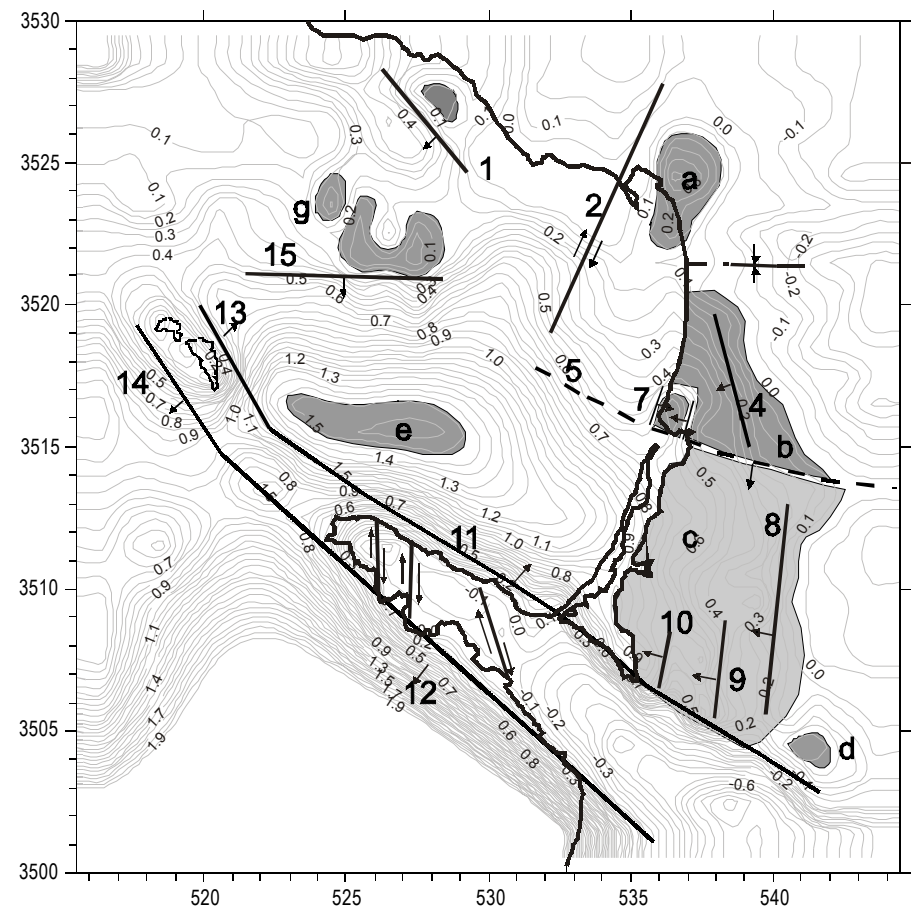

Figure 7. Proposed geological model after the interpretation of gravity and magnetic data using three-dimensional inversion. Proposed faults are numbered. Lower case letters represent basins or mounts. Level curves represent the topography of the three-dimensional basement every $50 \mathrm{~m}$.

Figura 7. Modelo geológico propuesto después de la interpretación de datos gravimétricos y magnéticos mediante inversión tridimensional. Los números indican las fallas propuestas y las letras minúsculas las cuencas 0 elevaciones. Las curvas de nivel representan la topografía del basamento tridimensional cada $50 \mathrm{~m}$. 
kilometers 535 and 540 UTM there are changes in the slope that may correspond to faults $\mathbf{1 0}, \mathbf{9}$ and $\mathbf{8}$ (fig. 7). At the end of the profile there is a small pond that corresponds to the El Zorrillo basin, $300 \mathrm{~m}$ in depth.

Profile A (fig. 4, 6b) goes N-S. In the south, persistent features of the peninsula and Agua Blanca faults are visible. The deepest part of the basin $(1600 \mathrm{~m})$ is located around kilometer 3515. Between kilometers 3520 and 3529 there are several structural features, among them faults 1 and $\mathbf{1 5}$. A more detailed morphological analysis could reveal other features; however, the most important are shown here.

Line B (figs. 4, 6c) shows several features, of which fault 5 is the clearest. It is located in the middle of the valley, splitting it structurally in two: Maneadero Valley to the south and Chapultepec Valley to the north. At kilometer 3520 (fig. 6b), the basement rises and the shape of the Valle Dorado syncline is observable (Schroeder, 1967) (figs. 2, 7). The Ensenada city basin is located to the north, with a maximum depth of $300 \mathrm{~m}$.

Through the profiles and the cross-sections of the 3-D model, a number of different structural features can be seen and correlated. In figure 7, all the structural features picked from the cross-section analysis are shown. The numbers are the faults and the lower case letters indicate volumetric features. Fault 5 correlates very well with the Arroyo San Carlos fault (fig. 2) and its path can be traced into the bay. This normal fault is dipping to the SW and divides Chapultepec Valley (b) from Maneadero Valley (c). From a hydrological point of view, we think that this feature does not affect the aquifers because they are shallower; hence, the only direct effect may be a change in the geometry of the water table. Unfortunately, potential methods are not very sensitive to the aquifer geometry. Fault $\mathbf{2}$ does not project through any of the profiles, but it correlates well with the strike-slip fault located onshore, which is the proposed harbor fault (fig. 7). It is not possible, however, to support González-Serrano's (1977) hypothesis that it extends to the Agua Blanca fault as shown in figure 2.

The Agua Blanca North and South faults (fig. 7) are distinctive features that control most of the tectonics within the Todos Santos Bay basin. The extension of the faults beyond the islands is not interrupted by the submarine Cañón de Punta Banda (fig. 2); from figure 2 it is obvious that the trace of these faults extends offshore, as shown by Line $\mathbf{C}$ (fig. 4, 5a). Following their trace near Todos Santos islands, the azimuth changes and becomes more NNW oriented. Another important feature observed in Line A (fig. 6b) is the difference in altitude of $1750 \mathrm{~m}$ between the highest elevation in the Punta Banda peninsula and the lowest in the basin.

The Valle Dorado syncline apparently is an isolated, unusual compressive feature, which affects the early Cretaceous Alisitos Formation andesites (Line B; fig. 6c).

Fault 4 was determined by Line $\mathbf{D}$ (fig. 5b). It seems to dip to the SW, forming a step (small basin) in the basement morphology much like faults 8,9 and 10, which are normal faults antes de llegar a la costa. Al este de la línea de costa se observa otra cuenca pequeña donde se localiza la ciudad de Ensenada.

La línea $\mathbf{D}$ (figs. 4, 5b) se extiende de Punta Banda a Valle Dorado. En la parte SW, la península de Punta Banda está flanqueada por las fallas de Agua Blanca y Maximinos. En este perfil la parte más profunda del fondo de la cuenca está a $1300 \mathrm{~m}$ y se torna más somero en dirección NE (lado derecho del perfil). Aunque el modelo es más suave en la inversión, los datos requerían dos inflexiones antes de llegar a las colinas alrededor de Valle Dorado. Estos cambios pequeños en la inclinación se interpretan como las fallas 5 y 4 (figs. 2, 7).

La línea $\mathbf{E}$ y su perfil asociado (figs. 4, 5c) van desde Punta Banda hasta el Valle de Maneadero. En el SW (lado izquierdo del perfil) hay una presencia persistente de la península de Punta Banda, aparte de las fallas de Agua Blanca y Maximinos. En la misma línea $\mathbf{E}$ se puede notar la extensión de la cuenca hacia el interior por debajo del Valle de Maneadero, donde alcanza una profundidad máxima de $1100 \mathrm{~m}$ que difiere de la profundidad de $1700 \mathrm{~m}$ reportada por Vázquez (1980). Al NE, hay un cambio en la pendiente que puede corresponder a la falla 5 en la figura 7.

La línea F (fig. 4) se extiende desde Punta Banda hasta Arroyo San Carlos, pasando por el Valle de Maneadero donde se hace más somera la cuenca, hasta $700 \mathrm{~m}$, en contraste con los $900 \mathrm{~m}$ mencionados por Vázquez (1980). Hay dos cambios en las pendientes asociados con las fallas 9 y 8 (figs. $5 \mathrm{~d}$, 7).

La línea $\mathbf{G}$ (figs. 4, 6a) va en dirección NW-SE paralela a la península de Punta Banda, empezando en las islas Todos Santos y acabando en El Zorrillo. En la parte NW, el basamento se hace más somero cerca de las islas, luego cae en la parte más profunda de la cuenca $(1400 \mathrm{~m})$ y se vuelve complejo entre los kilómetros 527 y 533 UTM (fig. 7). Este rasgo refleja los efectos tridimensionales de la península ya que la inversión fue en tres dimensiones. Entre los kilómetros 535 y 540 UTM hay cambios en la pendiente que pueden corresponder a las fallas 10, 9 y 8 (fig. 7). Al final del perfil hay una pequeña hondonada que corresponde a la cuenca de El Zorrillo de $300 \mathrm{~m}$ de profundidad.

El perfil A (figs. 4, 6b) corre N-S. En el sur se ven rasgos persistentes de las fallas de Agua Blanca y la península. La parte más profunda de la cuenca $(1600 \mathrm{~m})$ se localiza alrededor del kilómetro 3515. Entre los kilómetros 3520 y 3529 hay varios rasgos estructurales, entre ellos las fallas 1 y 15 . Un anánlisis morfológico más detallado podría revelar otras características; sin embargo, aquí se muestran las más importantes.

La línea B (figs. 4, 6c) muestra varios rasgos, siendo el más evidente la falla 5, que se localiza en medio del valle, dividiéndolo estructuralmente en dos: el Valle de Maneadero al sur y el Valle de Chapultepec al norte. En el kilómetro 3520 (fig. 6b), el basamento se eleva y se puede observar la forma del sinclinal de Valle Dorado (Schroeder, 1967) (figs. 2, 7). La cuenca de la ciudad de Ensenada se sitúa al norte, con una profundidad máxima de $300 \mathrm{~m}$.

Los perfiles y las secciones transversales del modelo tridimensional permiten ver y correlacionar varios rasgos 
with the downthrow block in the direction that the steps induce the sinking of the basement under the bay. At the same time these three faults interact with the principal trace of the Agua Blanca fault and control the morphology of the Maneadero basin.

Fault 5 follows the Arroyo San Carlos river bed and extends offshore in Ensenada Bay, where it possibly connects with fault $\mathbf{2}$. Fault $\mathbf{7}$ bounds what we believe is a micro-basin, although further evidence is necessary. These features are indicated by the area of four prismatic bodies and there are enough gravity and magnetic data (fig. 3a, c), though there seems to be relevance to the magnetic data but not to gravity (fig. $3 \mathrm{a}-\mathrm{d}$ ).

The Ensenada basin (a in fig. 7) seems to be a closed basin, reaching a maximum depth of $350 \mathrm{~m}$. El Zorrillo is another closed area, with a maximum depth of $300 \mathrm{~m}$. Faults $\mathbf{1}$ and $\mathbf{1 4}$ are necessary steps for the sinking of the gravity and magnetic basement into the bay. We suggest that features $\mathbf{g}, \mathbf{f}$ and $\mathbf{h}$ (fig. 7) are topographic highs and do not correspond to the structural features of the andesitic rocks exposed by the erosion process. One of these highs corresponds to El Bajo San Miguel.

The main feature of the basin is the minimum of $1600 \mathrm{~m}(\mathrm{e})$ close to the Agua Blanca fault (s), which indicates that in this area the main component of the fault is the vertical sense, and it is therefore responsible for the depth of the basin. The strike of the minimum is close to $\mathrm{E}-\mathrm{W}$ but when we consider the wider semi-axe, this seems more parallel to the Agua Blanca fault strike, following the direction of the tectonic stresses imposed by the fault.

\section{Tectonic environment}

The north branch of the Agua Blanca fault plays an important role in the development of Todos Santos Bay. Within this area, the fault passes offshore along the north side of the Punta Banda ridge, where it marks the steeply dipping contact between the basement rocks of the peninsula and the thick fill sediments in Todos Santos Bay. Here, the fault makes a sharp turn from almost $\mathrm{E}-\mathrm{W}$ orientation to $\mathrm{N} 25^{\circ}-35^{\circ} \mathrm{W}$ strike. Along the Punta Banda ridge numerous marine terraces (eleven) are elevated (Ortlieb, 1979), which indicates that several processes have occurred producing a great amount of uplift as well as eustatic movements (Orme, 1974). Gastil et al. (1975) and Legg et al. (1991) interpreted Todos Santos Bay as a typical pull-apart basin and the Punta Banda ridge as a horst. However, it is possible that the Todos Santos basin during the Mesozoic time was acting as a fore-arc basin and during that time some extensional deformation may have occurred as fore-arc sedimentation was taking place. Syndepositional folding occurred at the same time that normal faults trending parallel to the tectonic strike were developed. Later this deformation pattern changed when the tectonic regime changed from subduction to a strike-slip (Dickinson, 1995, p. 237). Nevertheless, the Todos Santos Coastal Plain has been affected by different tectonic estructurales. En la figura 7 se muestran todos los rasgos estructurales selectos del análisis de los cortes. Los números representan las fallas y las letras minúsculas indican aspectos volumétricos. La falla 5 se correlaciona bien con la falla del Arroyo San Carlos (fig. 2) y su ruta puede trazarse hasta la bahía. Esta falla normal se inclina hacia el SW y divide el Valle de Chapultepec (b) del Valle de Maneadero (c). Desde un punto de vista hidrológico, no se piensa que este rasgo esté afectando los acuíferos, ya que éstos son más someros; por tanto, el único efecto directo puede ser un cambio en la geometría del nivel de agua subterránea. Desafortunadamente, los métodos potenciales no son muy sensibles a la geometría de los acuíferos. La falla 2 no se proyecta en ninguno de estos perfiles, pero se correlaciona bien con la falla de rumbo hacia la tierra, que es la propuesta falla del puerto (fig. 7); sin embargo, no es posible apoyar la hipótesis de González-Serrano (1977) de que ésta se extiende hasta la falla de Agua Blanca, como se muestra en la figura 2.

Las fallas de Agua Blanca Norte y Sur (fig. 7) son rasgos distintivos que controlan la mayor parte de la tectónica dentro de la cuenca de la Bahía de Todos Santos. La extensión de las fallas más allá que las islas no es interrumpida por el Cañón de Punta Banda (fig. 2) y, de la figura 2, es obvio que estas fallas se extienden mar adentro como lo demuestra la línea $\mathbf{C}$ (figs. 4, 5a). Si se sigue su huella, cerca de las islas Todos Santos cambia el acimut a una orientación NNW. Otro rasgo importante que muestra la línea A (fig. 6b) es la diferencia de altura de $1750 \mathrm{~m}$ entre la mayor elevación en la península de Punta Banda y la menor en la cuenca.

El sinclinal de Valle Dorado aparentemente es un rasgo compresivo inusual aislado, que afecta las andesitas del Cretácico temprano de la Formación Alisitos (línea B; fig. 6c).

La falla 4 fue determinada por la línea $\mathbf{D}$ (fig. 5b). Parece inclinarse al SW formando un escalón (cuenca pequeña) en la morfología del basamento muy similar a las fallas 8,9 y $\mathbf{1 0}$, las cuales son fallas normales con el bloque de abajo en la dirección de los escalones que inducen el hundimiento del basamento debajo de la bahía. Al mismo tiempo, estas tres fallas interactúan con la huella principal de la falla de Agua Blanca y controlan la morfología de la cuenca de Maneadero.

La falla 5 sigue el cauce del Arroyo San Carlos y se extiende mar adentro en la Bahía de Ensenada, donde posiblemente se junte con la falla 2 . La falla 7 rodea lo que creemos es una microcuenca, aunque se requiere mayor evidencia. Estos rasgos están indicados por el área de cuatro cuerpos prismáticos; además existen suficientes datos gravimétricos y magnéticos (fig. 3a, c), aunque parece tener relevancia para los datos magnéticos pero no para los gravimétricos (fig. 3a-d).

La cuenca de Ensenada (a en fig. 7) parece ser una cuenca cerrada, alcanzando una profundidad máxima a $350 \mathrm{~m}$. El Zorrillo is otra área cerrada, con una profundidad máxima a $300 \mathrm{~m}$. Las fallas 1 y $\mathbf{1 4}$ son escalones necesarios para el hundimiento del basamento gravimétrico y magnético en la bahía. Se sugiere que los rasgos $\mathbf{g}, \mathbf{f}$ y h (fig. 7) son elevaciones topográficas y no corresponden a las características estructurales de 
regimes. The most recent is associated with the tectonism within the continental borderland where the Agua Blanca fault plays an important role. This major structural feature is considered to be unstable because it changes geometry along the length and through time. This means that if the Agua Blanca fault has a stable configuration, then the lateral slip will take place along a single fault within the shear zone and all other faults will be pure dip-slip and oriented parallel to the strike-slip fault (Legg et al., 1991).

In the 3-D gravity and magnetic model obtained using all available data from different authors, the major problem was to homogenize the different data sets because they were corrected with different slabs for the Bouguer anomaly. Thanks to the software used, it was not necessary to move the vertical position of the original measurements. The responses of the 3-D model computed in the place of the observations fit very well with the original observation. We applied a smoother inversion in order to avoid unnecessary 3-D small effects in the gravity and magnetic basement. This gives us more confidence in the 3-D variations obtained, and we assume that the data needed those structural features.

The geological model corroborates the existence of all structural features mentioned by previous authors, such as the Agua Blanca fault, the San Carlos fault that can also be a step form along the development of the Maneadero half-graben, one of the faults in Maneadero Valley, and the fault oriented almost $\mathrm{N}-\mathrm{S}$ that extends into Ensenada harbor.

The model also adds new knowledge about the Ensenada harbor fault that extends offshore into the bay, deforming the basin. At least three faults in Maneadero Valley were considered responsible for the sinking of the basement. One fault is considered to extend into Chapultepec Valley and apparently ends against the San Carlos fault. The Agua Blanca faults are drawn between Punta Banda and the islands and projected to the north with a change of strike arriving at Todos Santos islands. Between the islands and San Miguel at least two faults are recognized and justify the rise of the basin on the NW side with the presence of some mounts such as the Bajo San Miguel. The geometry of the Ensenada basin and its maximum depth were determined. The city of Ensenada and El Zorrillo ranch basins are considered close, and a maximum depth was estimated for each one. The elongated shape of the basin confirms that this is tectonically controlled by the Agua Blanca faults with some perpendicular faults as deepen steps explaining how this basement historically sank as a half-graben. It is possible that other faults exist but we do not yet have enough resolution in the data to confirm their existence.

\section{Acknowledgements}

Thanks to the anonymous reviewers for their comments. Thanks to Humberto Benítez-Pérez for his help in the edition of figures; and to Karem Englander for helping us to improve the final presentation. las rocas andesíticas expuestas por el proceso de erosión. Una de estas elevaciones es el Bajo San Miguel.

La principal característica de esta cuenca es el mínimo de $1600 \mathrm{~m}$ (e) cerca de la falla de Agua Blanca (s), el cual indica que en esta área el componente principal de la falla es la dirección vertical $\mathrm{y}$, consecuentemente, es responsable de la profundidad de la cuenca. El rumbo del mínimo es alrededor de E-W, pero cuando se considera el semieje más amplio, parece estar más paralelo al rumbo de la falla de Agua Blanca, siguiendo la dirección de los esfuerzos tectónicos impuestos por la falla.

\section{Ambiente tectónico}

El brazo norte de la falla de Agua Blanca juega un papel importante en el desarrollo de la Bahía de Todos Santos. Dentro de esta área, la falla pasa mar adentro en el lado norte de la cordillera de Punta Banda, donde marca el contacto inclinado entre las rocas del basamento de la península y los sedimentos gruesos en la Bahía de Todos Santos. Aquí, la falla cambia abruptamente de dirección de casi $\mathrm{E}-\mathrm{W}$ a un rumbo de $\mathrm{N} 25^{\circ}-35^{\circ} \mathrm{W}$. A lo largo de la cordillera de Punta Banda se elevan numerosas (once) terrazas (Ortlieb, 1979), lo que demuestra la ocurrencia de varios procesos, produciendo considerable levantamiento y movimentos eustáticos (Orme, 1974). Gastil et al. (1975) y Legg et al. (1991) interpretaron la Bahía de Todos Santos como una típica cuenca extensional (pullapart basin) y la cordillera de Punta Banda como un horst. Sin embargo, es posible que durante el Mesozoico la cuenca de Todos Santos actuara como una cuenca de ante-arco, y que mientras tanto haya habido alguna deformación extensional durante el proceso de sedimentación de ante-arco. Simultáneamente con el desarrollo de las fallas normales paralelas al rumbo tectónico ocurrió un plegamiento sindeposicional. Posteriormente cambia este patrón de deformación cuando el régimen tectónico cambia de subducción a falla de rumbo (Dickinson, 1995, p. 237). No obstante, la Planicie Costera de Todos Santos ha sido afectada por diferentes regímenes tectónicos, el más reciente asociado con el tectonismo dentro del borde continental en el que la falla de Agua Blanca juega un papel importante. Este rasgo estructural principal se considera inestable, ya que cambia de geometría a lo largo de su extensión y en el tiempo. Esto significa que si la falla de Agua Blanca tiene una configuración estable, entonces el deslizamiento lateral ocurrirá a lo largo de una sola falla dentro de la zona de deslizamiento y todas las otras fallas serán de buzamiento y orientadas paralelamente a la falla de rumbo (Legg et al., 1991).

En el modelo tridimensional gravimétrico y magnético utilizado, el principal problema consistió en homogeneizar los diferentes conjuntos de datos, ya que éstos fueron corregidos con diferentes capas para la anomalía de Bouguer. Por el tipo de programa utilizado no fue necesario mover la posición vertical de las mediciones originales. Las respuestas del modelo tridimensional estimadas en el lugar de las observaciones se ajustaron muy bien a la observación original. Se aplicó una 


\section{References}

Aguero M., G.A. (1986). Características de la bahía de Todos Santos y áreas costeras adyacentes. Tesis de licenciatura, Universidad Autónoma de Baja California, Ensenada, Baja California.

Allen, C.R., Silver, L.T. and Stehli, F.G. (1960). Agua Blanca fault: A major transverse structure of northen Baja California, Mexico. Bull. Geol. Soc. Am., 71: 457-482.

Allison, E.C., (1955). Middle Cretaceous Gastropoda from Punta China, Baja California, Mexico. J. Paleontol., 20: 400-432.

Aranda, F.J. (1983). Estudio de minerales pesados como trazadores de la corriente litoral en la Bahía de Todos Santos, B.C. Tesis de licenciatura, Universidad Autónoma de Baja California, Ensenada, Baja California 78 pp.

Consejo de Recursos Naturales No Renovables (1962). Aeromagnetic data base from Continental Mexico. Presently: Consejo de Recursos Naturales de México.

Cruz F., A. (1986). Gravimetría de la cuenca de San Carlos. Tesis de maestría, Centro de Investigacion Científica y de Educación Superior de Ensenada, Baja California, 98 pp.

Dickinson, R.W. (1995). Forearc Basin. In C.J. Busby and R.V. Ingersoll (eds.), Tectonics of Sedimentary Basins. Chapter 6, pp. 221-261.

Dowdy, P.R. (1977). A gravity survey of Valle de Mandadero, Baja California. San Diego State Univ., Geological Sciences, Senior Rep., 52 pp.

Fabriol, H., Martínez, M. y Vázquez, R. (1982). Mediciones gravimétricas y telúricas en el valle de Maneadero, Ensenada, Baja California. Geofís. Int., 21: 41-55.

Gallardo-D., L.A., Pérez-Flores, M.A. and Gómez-Treviño, E. (2003). A versatile algorithm for joint 3-D inversion of gravity and magnetic data. Geophysics, 68(3): 1-11.

Gastil, R.G., Phillips, R. and Allison, C.E. (1975). Reconnaissance geology of the state of Baja California. Geol. Soc. Am. Mem., $140,170 \mathrm{pp}$.

González, J.J. and Suárez, F. (1984). Geological and seismic evidence of a new branch of the Agua Blanca fault. Geophys. Res. Lett., 11(1): 42-45.

González-Fernández, A., Martín, A.B. y Paz, S. (2000). Identificación de fallamientos en la península de Punta Banda, B.A. a partir de datos de topografía, gravimetría y magnetometría. GEOS, 20: 98-106.

González-Serrano, A. (1977). Anomalías gravimétricas y magnéticas de la bahía de Todos Santos. Tesis de licenciatura, Universidad Autónoma de Baja California, Ensenada, Baja California, 78 pp.

Hummel, P. (1972). Geothermal investigation along the Agua Blanca fault. San Diego State Univ., Senior Rep., 21, 37 pp.

Legg, M.R. (1985). Geologic structure and tectonics of the inner continental borderland offshore northern Baja California, Mexico. U.C. Santa Barbara, unpublished Ph.D. thesis, 408 pp.

Legg, R.M., Wong, V. and Suárez-V., F. (1991). Geologic structure and tectonics of the inner continental borderland of northern Baja California. In: P. Dauphin and B. Simoneit (eds.), The Gulf and Peninsular Province of the Californias. AAPG Mem., 47: 145-177.

Orme, A.R. (1974). Quaternary deformation of marine terraces between Ensenada and El Rosario, Baja California. In: G. Gastil and J. Lillegraven (eds.), Geology of Peninsular California. AAPG, SEPM and SEG Pacific section, guidebook, pp. 67-79.

Ortega, M.A. (1988). Neotectónica de un sector de la falla de Agua Blanca, Valle Agua Blanca (Rancho la Cocina-Rancho Agua Blanca), Baja California, Mexico. Tesis de maestría, Centro de Investigación Científica y de Educación Superior de Ensenada, Baja California, México, 146pp. inversión suavizadora con el fin de evitar pequeños efectos tridimensionales innecesarios en el basamento gravimétrico y magnético. Esto proporcionó más confianza en las variaciones tridimensionales obtenidas, y suponemos que los datos requerían estas características estructurales.

El modelo geológico corrobora la existencia de todos los rasgos estructurales mencionados por los autores de trabajos previos, tales como la falla de Agua Blanca, la falla de San Carlos que también puede ser una forma escalonada a lo largo del desarrollo del semigraben de Maneadero, una de las fallas del Valle de Maneadero, y la falla orientada casi N-S que se extiende al interior del puerto de Ensenada.

El modelo también aporta nuevo conocimiento acerca de la falla del puerto de Ensenada que se extiende mar adentro en la bahía, deformando la cuenca. Al menos tres fallas del Valle de Maneadero se consideran responsables por el hundimiento del basamento. Se considera que una falla se extiende al Valle de Chapultepec y aparentemente termina contra la falla de San Carlos. Las fallas de Agua Blanca se dibujan entre Punta Banda y las islas, y se proyectan hacia el norte con un cambio de rumbo llegando a las islas Todos Santos. Entre las islas y San Miguel se reconocen al menos dos fallas que justifican la elevación de la cuenca en el lado NW, con la presencia de algunas elevaciones como el Bajo San Miguel. Se determinaron la geometría y la máxima profundidad de la cuenca de Ensenada. Las cuencas de la ciudad de Ensenada y del rancho El Zorrillo se consideraron de manera aproximada, y se estimó la máxima profundidad de cada una de ellas. La forma alargada de la cuenca confirma que ésta está tectónicamente controlada por la falla de Agua Blanca con algunas fallas perpendiculares como escalones de profundidad que explican históricamente de qué manera se hundió este basamento como semigraben. Es posible que existan otras fallas pero los datos no tienen la suficiente resolución como para confirmar su existencia.

\section{Agradecimientos}

Gracias a los revisores anónimos por sus comentarios, a Humberto Benítez-Pérez por su ayuda en la edición de las figuras y a Karem Englander por su ayuda en la presentación final del manuscrito.

Traducido al español por Christine Harris.

Ortega-Rivera, A.E., Ferrar, J.A., Hames, D.A., Archibald, R.G., Gastil, D.L., Kimbrough, M., Zentilli, M., Lopez-Martínez, G., Féraud and Buffet, G. (1997). Chronological constraints on the thermal and tilting history of the San Pedro Mártir pluton, Baja California, Mexico, from U/Pb, $40 \mathrm{Ar} / 39 \mathrm{Ar}$, and fission-track geochronology. Geol. Soc. America Bull., 109(6): 728-745.

Ortlieb, L. (1979). Quaternary shorelines around Baja California Peninsula, Mexico: Neotectonics implications (abs.). Geological Soc. Am., abstracts with programs, 11(7): 490.

Pou A., S. (1982). Estudio de la tectónica de las islas de Todos Santos, B.C., México. Tesis de licenciatura, Universidad Autónoma de Baja California, México, 50pp. 
Quintanilla-Montoya, A.L. (1984). Origen del deposito sedimentario de la isla norte de Todos Santos, B.C. Tesis de licenciatura, Universidad Autónoma de Baja California, México, 34 pp.

Quintanilla-Montoya, A.L. y Suárez-Vidal, F. (1992). Origen del deposito sedimentario de la isla norte de Todos Santos, B.C. Cienc. Mar., 18(1): 1-18.

Reineck, H.E. and Singh, I.B. (1980). Depositional Sedimentary Environments with Reference to Terrigenous Clastic. SpringerVerlag, Berlin, pp. 260-261.

Rockwell, K.T., Hatch, E.M. and Schug, L.D. (1987). Late Quaternary rates Agua Blanca and Borderland faults. Final Technical Rep. US Geol. Surv., 122 pp.

Ross, K.Y. (1981). The stratigraphy and sedimentology of upper Cretaceous sediments of southwestern California and Baja California, Mexico. Ph.D. thesis, Rice University, 603 pp.

Schroeder, J.E. (1967). Geology of a portion of the Ensenada quadrangle, Baja California, Mexico. M.Sc. thesis, San Diego State University, $74 \mathrm{pp}$.
Suárez, F., Armijo, R., Morgan, G., Bodin, P. and Gastil, R.G. (1991). Framework of recent and active faulting in northern Baja California. In: P. Dauphin and B. Simoneit (eds.), The Gulf and Peninsular Provinces of the Californias. AAPG Mem., 47: 285-200 pp.

Vázquez, G.R. (1980). Estudio de métodos potenciales con aplicaciones a geohidrología del valle de Maneadero. Tesis de maestría, Centro de Investigación Científica y de Educación Superior de Ensenada, Baja California, México.

Wong, V.M. (1980). Implicaciones tectónicas de la falla de Agua Blanca en la Bahía de Todos Santos. Tesis de maestría, Centro de Investigación Científica y de Educación Superior de Ensenada, Baja California, México, 79 pp.

Wong, O.V., Legg, M. y Suárez, F. (1987). Sismicidad y tectónica de la margen continental del sur de California (USA) y Baja California norte (México). Geofís. Int., 26(3): 459-478 pp. 